\title{
WATER QUALITY AND FISH DIVERSITY OF CHENGI RIVER OF KHAGRACHARI DISTRICT
}

\author{
Gulshan Ara Latifa*, Ahmad Kamruzzaman Majumder, \\ Md. Humayun Kabir and Arnab Chakma, \\ Department of Environmental Science, Stamford University Bangladesh, \\ Dhanmondi, Dhaka-1209, Bangladesh
}

\begin{abstract}
Chengi a major river of Khagrachari district is getting polluted day by day due to unplanned river management. Both primary and secondary data have been used to conduct this work. Primary data have been collected through extensive field work, questionnaire and sample collection. Water samples have been collected from three sampling station, namely Ganjapara, Chengi Bridge and Rubber factory sites. Water temperature is higher at different sampling stations in the study site than Bangladesh standards $\left(25^{\circ} \mathrm{C}\right)$ due to the direct hit of the sun. The maximum DO value is $5.8 \mathrm{mg} / 1$ at the sampling station one and the minimum is $5.3 \mathrm{mg} / 1$ at station three. So, it concluded that the DO value of the Chengi river is comparatively lower than the Bangladesh Standards. The water Temperature and $\mathrm{pH}$ is higher than the Bangladesh standards and the value of other parameters are very lower than the Bangladesh standards. In fish diversity, 10 families belonging to 6 orders were recorded and identified by the fin formula. The order Cypriniformes occupied 40\%, the order Perciformes which occupies $25 \%$ and the order Beloniformes, Siluriformes, Cyprinodontiformes occupied $10 \%$ and Mollusks and other invertebrates occupied 25\%, respectively in all cases. This work provides a complete picture of the water quality and also the fish diversity of the Chengi River. It will be helpful for water resource management and planning.
\end{abstract}

Key words: Fresh water, scarcity, depletion, water resource.

\section{INTRODUCTION}

Water is a unique resource because it is essential for aquatic life and it constantly cycles between the land and the atmosphere. The same water is also used for crop and animal production. Beside these, it can be shared with the public, aquatic and terrestrial ecosystems (Cooper et al. 1998). Water resources are of great environmental issues and studied by a wide range of specialists including hydrologists, engineers, ecologists, geologists and geo-morphologists (Kumar and Dua 2009). It has become an important issue for them as it affects not only human life but also the life of plants and animals. River water quality is a key concern as it is used for drinking and domestic purposes, irrigation and aquatic life including fish and fisheries (Uddin et al. 2014). Chengi River is one of the most potential sources of water that can meet the increasing demand of water.

"Author for correspondence: <gulshan_al@yahoo.com>.

@2019 Zoological Society of Bangladesh DOI: https://doi.org/10.3329/bjz.v47i2.44345 
throughout the Khagrachari district in dry seasons. Khagrachari is located in the south- eastern part of Bangladesh. In the east region of Bangladesh, it is considered to be the lifeline to business activities for both the hilly people and the plain land population (Parvin 2007). The river can play a vital role to contribute socio-economic structure of development as a developing country like Bangladesh. But the recent statistical scenario shows that water is polluting massively in the Chengi River due to disposal of untreated effluent from industrialization, municipality sewage, rubber factories, rubber dam, and riverbank erosion along with using excessive fertilizer for agricultural production due to which the water quality is polluting. Most of the farmers are depended on this river for their agricultural production. People use the water of this river for many purposes like drinking, irrigation, fisheries, domestic use, recreational purposes etc. So, this research provides a complete picture of the water quality of Chengi River at Khagrachari district with its fish diversity and the deviation with Bangladesh standard. The aim of this research is to analyze (a) To assess the water quality of the Chengi River and compare the present water quality status with Bangladesh standards. (b) To identify the fish diversity of the study area.

\section{MATERIAL AND METHODS}

Khagrachhari district is bordered by Tripura (Indian province) to the north, Rangamati and Chittagong districts to the south, Rangamati district to the east, Chittagong district and Tripura (Indian province) to the west (Fig. 1A). It is situated under Chittagong division. There are 3 Municipalities in Khagrachhari district, namely Khagrachhari, Ramgor and Matiranga. The number of Upazilas in Khagrachhari district is nine, namely Khagrachhari, Mohalchori, Manikchori, Panchori, Luxmichori, Dighinala, Matiranga, Ramgor and Guimara containing38 Unions, 120 Mauzas and 1702 villages (BBS 2011). Chengi is the longest river in Khagrachhari. Most of the areas of Khagrachhari are hilly areas. The main ethnic groups living in the district are Tripuras, Chakmas, Bengalis and Marmas.

Three sampling sites have been selected at Chengiriver randomly for conducting this work. The sampling stations were denoted by S-1, S-2 and S-3 respectively (Figure 1B). The first water sample was collected at $9.15 \mathrm{a} . \mathrm{m}$. in S-1 (Ganjpara) and the second sample was collected at 10.25 a.m. in S-2 (near Chengi Bridge) and the third sample was collected at 11.7 a.m. in S-3 (near Rubber factory). The water samples were analyzed after collection.

The entire sampling site coordinate measured by the GPS tracker. Sample-1 at Ganjpara is located between $23^{\circ} 6^{\prime} 13^{\prime \prime} \mathrm{N}$ latitude and $91^{\circ} 58^{\circ} 72^{\circ} \mathrm{E}$ longitude, 
Sample 2 at Chengi bridge is located between $23^{\circ} 6^{\prime} 21^{\prime \prime} \mathrm{N}$ latitude and $91^{\circ} 58^{\prime} 13^{\circ} \mathrm{E}$ longitude and sample 3 at Rubber factory is located between $23^{\circ}$ $7 ` 34^{\prime} \mathrm{N}$ latitude and $91^{\circ} 57^{\circ} 93^{\circ} \mathrm{E}$ longitude (Table 1).

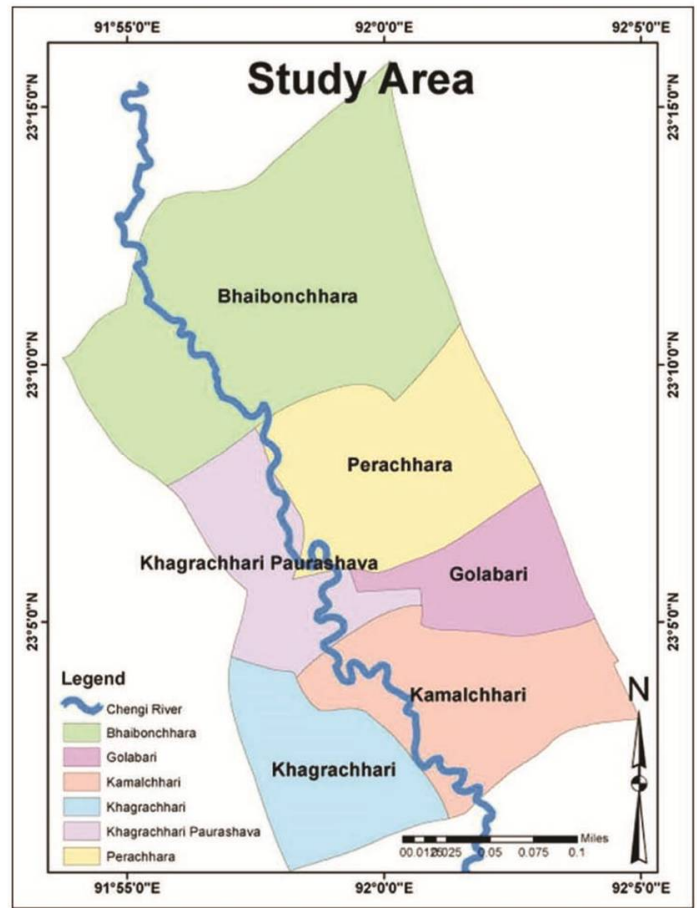

Fig. 1A.Study area

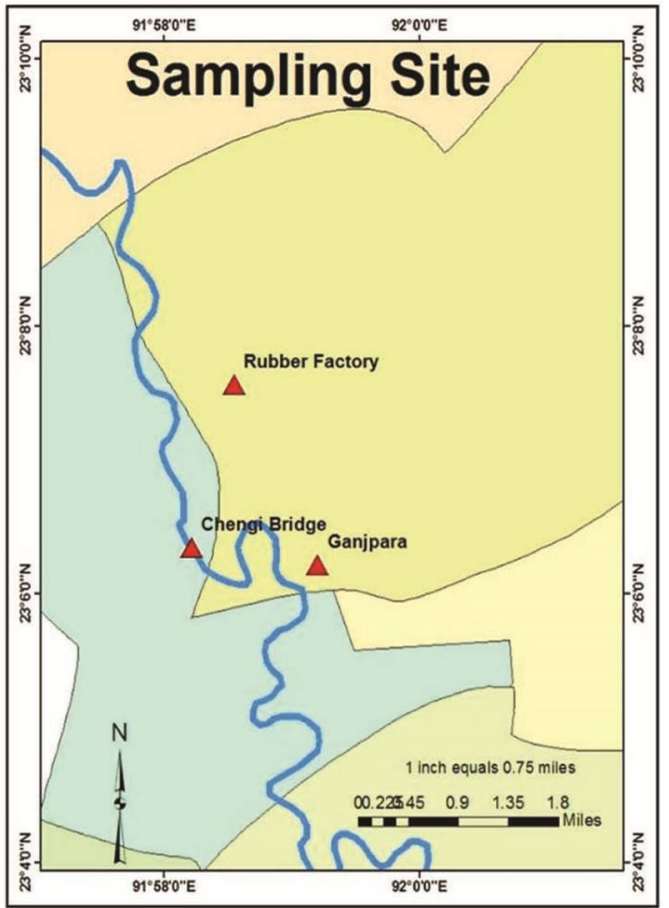

Fig. 1B. Sampling sites

Table 1. The location of sampling sites and data collection period

\begin{tabular}{|c|c|c|c|c|}
\hline \multirow{2}{*}{$\begin{array}{l}\text { Sample } \\
\text { No. }\end{array}$} & \multirow{2}{*}{$\begin{array}{l}\text { Sampling } \\
\text { site }\end{array}$} & \multirow[t]{2}{*}{ Time } & \multicolumn{2}{|c|}{ Geographic coordinate } \\
\hline & & & Latitude & Longitude \\
\hline 1. & S-1: Ganjapar & 9:15 a.m. & $23^{\circ} 6^{\prime} 13^{\prime \prime} \mathrm{N}$ & $91^{\circ} 58^{\circ} 72^{\circ \mathrm{E}}$ \\
\hline 2. & S-2: Chengi bridge & 10:29 a.m. & $23^{\circ} 6^{\prime} 21^{\prime \prime} \mathrm{N}$ & $91^{\circ} 58^{\prime} 13^{\circ} \mathrm{E}$ \\
\hline 3. & S-3: Rubber factory & 11:7 a.m. & $23^{\circ} 7^{\prime} 34^{\prime \prime} \mathrm{N}$ & $91^{\circ} 57^{\circ} 93^{\circ} \mathrm{E}$ \\
\hline
\end{tabular}

Source: GPS based ground survey, 2017.

For taxonomic and biometric study work a number of specimens were collected and preserved for subsequent laboratory study. Boats and trawlers were used to reach the sample location. The cast net, seine net, push net, dip net were used for collecting fish samples. The specimens were preserved in $10 \%$ formalin. For Laboratory use scale, Vernier slide calipers, pair of forceps, Petri dish, scalpel and hand gloves were used for the identification of the fishes. 
Water samples were collected from the Chengi river of Khagrachari in dry seasons on May 1, 2017 and tested for physical qualities and chemical contents. For further analysis samples were collected in 1.5 liter polypropylene bottles. Prior to sample collection sampling bottles were prepared following standard procedures. During the sample collection, all sample bottles were labeled as required. Total three sampling stations were selected. GPS data were collected by GPS machine at the sampling sites.

Data collected from the morphometric and meristic features, for morphometric characters total length, standard length, pre-dorsal length etc. were taken and for meristic study the ratio of the different morphological parameters were taken.

Standard procedures were used to analyze the physico-chemical parameters of water samples. Visual inspection for transparency, GPS Meter (Garmin etrex 10) for geographic coordinate, thermometer (Eurolab ST9268B) (Graduated 0 to $100^{\circ} \mathrm{C}$ ) for temperature, DO meter for dissolved oxygen, single electrode $\mathrm{pH}$ meter (Jenway pH meter, model 3305) for $\mathrm{pH}$, EC meter (range 0-1999 $\mu \mathrm{S} / \mathrm{cm}$ ) for electrical conductivity and TDS (model TDS3/TEMP) meter (range 0-9990 $\mathrm{ppm}$ ) for Total dissolved solids were used in the field for measuring some physico-chemical parameters. For measuring the physico-chemical parameters standard procedure was followed according to the instruments manual and reading was taken after stable the reading.

The taxonomic study of identification of fish up to the genera and species of fish was indentified according to Talwar and Jhingran (1991) and Rahman (2005).

For the statistical analysis and tabulation, Microsoft Excel 2007 and ArcGIS 10.2.1 software have been used. All the graphs and tables were also illustrated by using this Microsoft Excel 2007 software. The statistical measures such as number and percent distribution were used for describing the variables of the study.

\section{RESULTS AND DISCUSSION}

Water samples were collected from the Chengi river of Khagrachari district during summer season and some physico-chemical parameters were tested. Three sampling points were selected to collect the field data. The important water quality parameters, such as temperature, $\mathrm{pH}$, TDS, DO, turbidity and EC were analyzed and also identified the fish biodiversity of the study site.

\section{Physico-chemical parameters of the Chengi river}

Total dissolve solid: Fig.2 shows the total dissolve solid (TDS) of the three sampling sites of the Chengi river. Results revealed that the maximum TDS 
value in the sampling site three, namely Rubber factory that was $53 \mathrm{ppm}$. On the other hand, the minimum TDS values were found both in the sampling site two (Ganjpara) and three (Chengi bridge) that was 51 ppm (Fig.2). It is was interesting that the total dissolve solid was same both in the S-1 and S-2. The TDS value of Bangladesh standard for drinking water is 1000 ppm (ECR 1997) which is very high than the Chengi river.

Dissolved oxygen: Fig. 3 illustrated the dissolved oxygen value of different sampling stations of the Chengi River. Standard value of the dissolve oxygen for drinking water in Bangladesh is 6 (ECR 1997). But, the analysis showed that maximum DO value was $5.8 \mathrm{mg} / 1$ at the sampling station one (Ganjpara) and the minimum DO value was $5.3 \mathrm{mg} / \mathrm{l}$ at the sampling station Rubber factory (Fig. 3). So, it can be concluded that the DO value of the Chengi river is comparatively low than the Bangladesh standards.

Total Dissolved Solid (TDS)

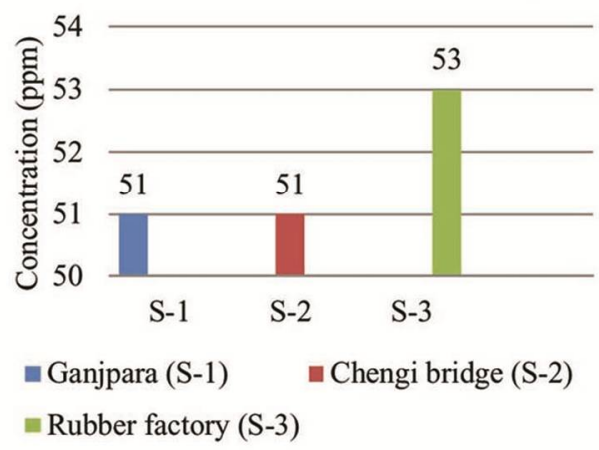

Fig. 2. TDS value of different sampling station at Chengi river
Dissolved Oxygen (DO)

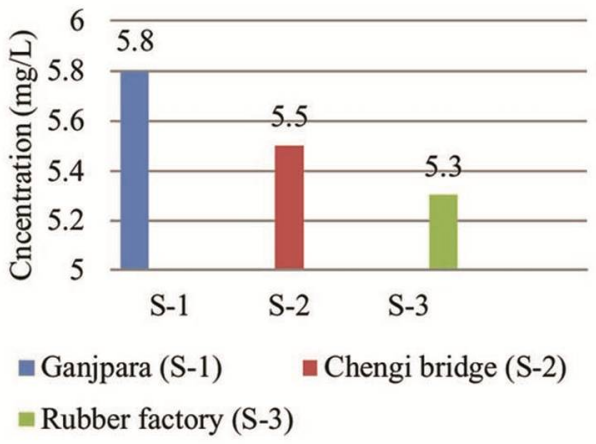

Fig. 3. DO value of different sampling station at Chengi river

pH: Fig. 4 demonstrates the level of $\mathrm{pH}$ at different sampling stations of the study site. According to ECR-1997, the ideal $\mathrm{pH}$ value of drinking water for Bangladesh ranges between 6.5 and 8.5 whereas the maximum $\mathrm{pH}$ level are found at the sampling site three (Rubber factory) that was 9.7 and the minimum $\mathrm{pH}$ levels were at the sampling station one (Ganjpara) that is 9.1. Fish cultivation and production of microorganism are very difficult at the Chengi river due to the high $\mathrm{pH}$ value.

Electrical conductivity: Electrical conductivity of different sampling stations in the study site were slight different. Bangladesh standard of electrical conductivity minimum is $500 \mu \mathrm{S} / \mathrm{cm}$ (ECR 1997) whereas the average tested result was low than the $\mathrm{BD}$ standard. The results revealed that maximum EC value were found at the sampling station two (Chengi bridge) which was 135 
$\mu \mathrm{S} / \mathrm{cm}$ and the minimum EC value was at the sampling station one (Ganjpara) which was $131 \mu \mathrm{S} / \mathrm{cm}$ (Fig. 5).

pH

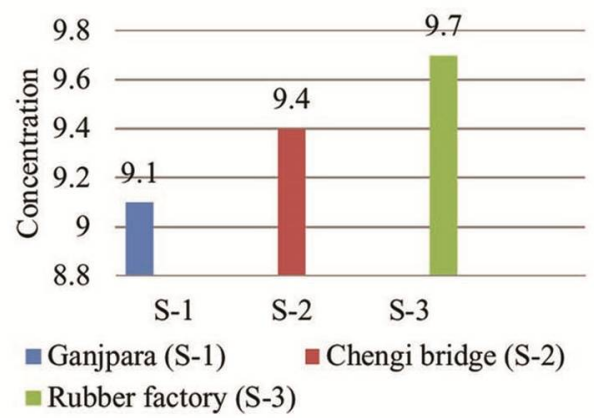

Fig. 4.pH values of different sampling station of the Chengi river.
Electrical Conductivity (EC)

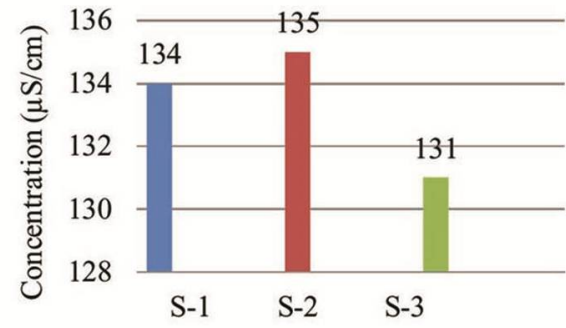

- Ganjpara (S-1) $\quad$ Chengi bridge (S-2)

- Rubber factory (S-3)

Fig. 5. EC values of different sampling station of the Chengi river.

Temperature: Fig. 6 illustrates the temperature of different sampling stations of the Chengi river. The result showed that maximum temperature was $31.1^{\circ} \mathrm{C}$ in $\mathrm{S} 3$ (Rubber factory) and the minimum temperature was $29.1^{\circ} \mathrm{C}$ at Ganjpara. Temperature was higher at different sampling station in the study site than Bangladesh (ECR 1997) standards $\left(25^{\circ} \mathrm{C}\right)$ due to the direct hit of the sun.

Transparency: Transparency represents the clearness of water (Fig. 7). In the study site, the highest transparency value was seen at Ganjpara (S 1) that was 12 inch, and lowest value was 9 inch at Rubber factory (S 3).

Temperature

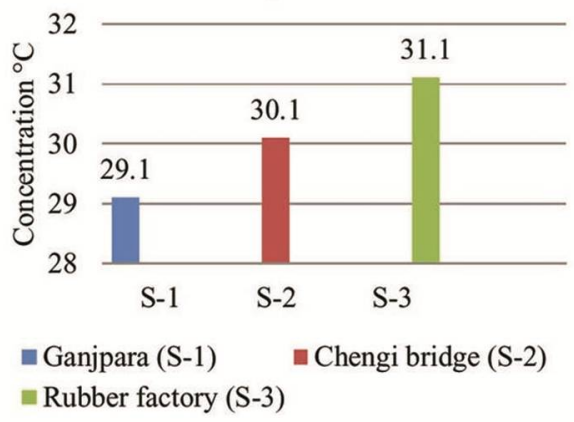

Fig. 6. Temperature of different sampling station of the Chengi river.
Transparency

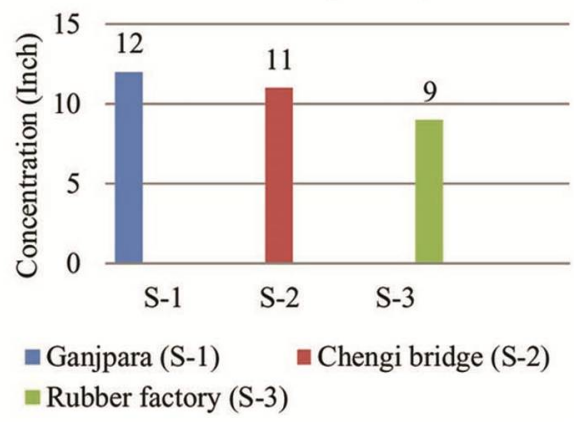

Fig. 7. Transparency value of different sampling station of the Chengi river.

Turbidity: Fig. 8 shows the turbidity value of different sampling stations of the Chengi river. The results revealed that turbidity values of the sampling sites were very high than Bangladesh standard. Bangladesh standard of Turbidity value is $10 \mathrm{NTU}$ where the turbidity value at the sampling station one (Ganjpara) was on average 30 NTU. 


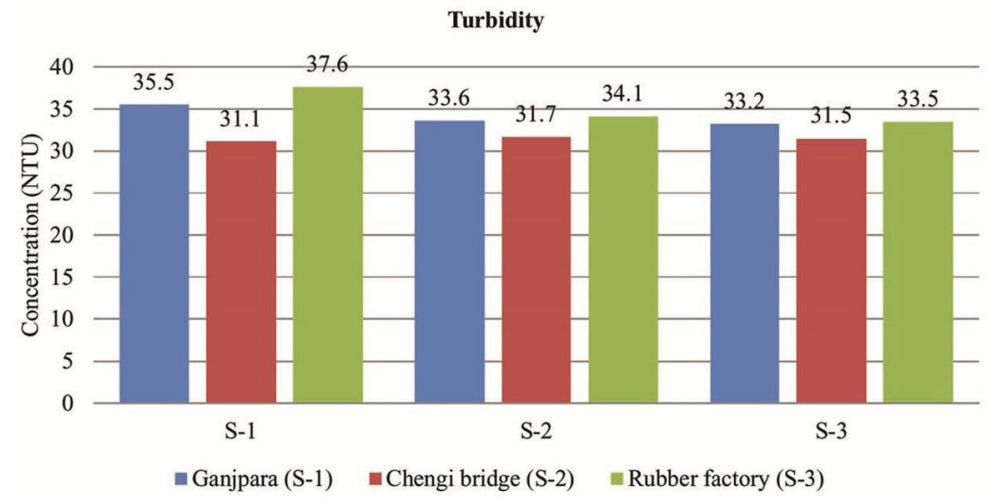

Fig. 8. Turbidity value of different sampling stations of the Chengiriver.

\section{Comparison between Bangladesh standards of water quality and the tested data}

Most of the value of the physico-chemical parameters of the Chengi river is lower than the Bangladesh standard. Only the value of temperature and the $\mathrm{pH}$ is higher than the Bangladesh standards (Table 2).

Table 2. Comparison between the water quality of Bangladesh standards and the results

\begin{tabular}{llllll}
\hline Water quality parameters & Unit & BDS & Station-1 & Station-2 & Station-3 \\
\hline Total dissolve solids (TDS) & $\mathrm{ppm}$ & 1000 & 51 & 51 & 53 \\
Dissolve oxygen & $\mathrm{mg} / \mathrm{c}$ & 6 & 5.8 & 5.5 & 5.3 \\
$\mathrm{pH}$ & - & 7.5 & 9.1 & 9.4 & 9.7 \\
Electrical conductivity & $\mu \mathrm{S} / \mathrm{cm}$ & 500 & 134 & 135 & 131 \\
Temperature of water & ${ }^{\circ} \mathrm{C}$ & 25 & 29.1 & 30.1 & 31.1 \\
Transparency & $\mathrm{Inch}$ & - & 12 & 11 & 9 \\
Turbidity & $\mathrm{NTU}$ & 10 & 34.1 & 31.4 & 35.1 \\
\hline
\end{tabular}

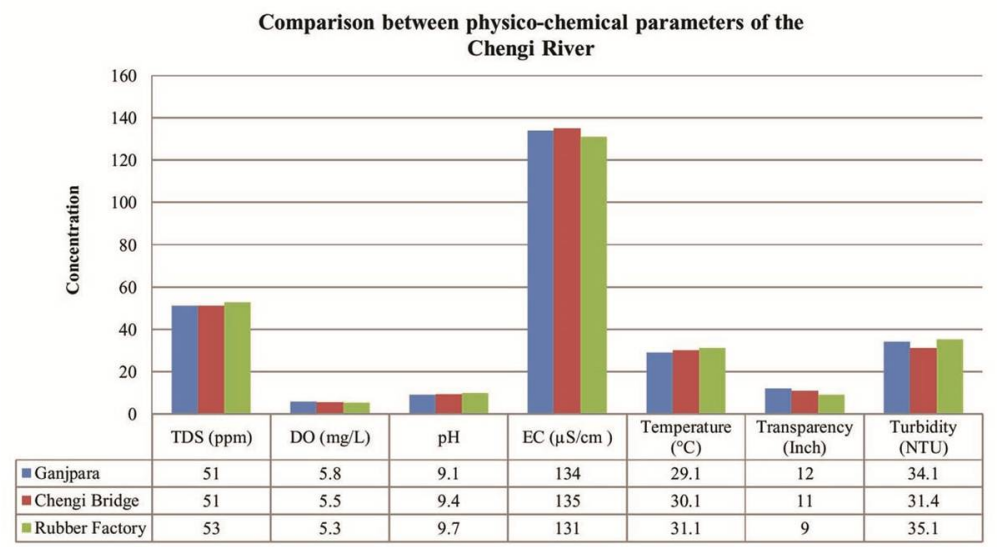

Fig. 9. Comparison between water quality of Bangladesh standards and the results. 
Fish diversity of the Chengi river: The fish samples were identified with the help of taxonomic key suggested by Talwar and Jhingran (1991). The order, family, scientific and the Bengali names of the fishes are given in the Table 3.

Table 3. Showing the fish diversity of the Chengi river at Khagrachari

\begin{tabular}{|c|c|c|c|c|c|}
\hline Order & Family & $\begin{array}{l}\text { Scientific } \\
\text { name }\end{array}$ & $\begin{array}{l}\text { English } \\
\text { name }\end{array}$ & $\begin{array}{l}\text { Local } \\
\text { name }\end{array}$ & $\begin{array}{l}\text { Fin formula } \\
\text { of the fish }\end{array}$ \\
\hline Siluriformes & Olyridae & Olyralongicaudata & $\begin{array}{l}\text { Bannertail } \\
\text { Catfish, } \\
\text { Longtail } \\
\text { Catfish }\end{array}$ & $\begin{array}{l}\text { Bot } \\
\text { Shinghi }\end{array}$ & $\begin{array}{l}\text { D } 1 / 7 ; \mathrm{P}_{1} \\
\mathrm{I} / 6 ; \mathrm{P}_{2} 1 / 5 ; \\
\text { A } 18-19\end{array}$ \\
\hline Elopiformes & Ophichthidae & Pisodonophisboro & $\begin{array}{l}\text { Rice Paddy } \\
\text { Eel, Boro } \\
\text { Snake-eel }\end{array}$ & $\begin{array}{l}\text { Kharu, } \\
\text { Hijra }\end{array}$ & $\begin{array}{l}\text { D. } 353 ; \text { P. } \\
\text { 113; A. } 267\end{array}$ \\
\hline $\begin{array}{l}\text { Cyprinodonti- } \\
\text { formes }\end{array}$ & Cyprinodontidae & Aplocheiluspanchax & $\begin{array}{l}\text { Top-minnows, } \\
\text { Blue panchax }\end{array}$ & $\begin{array}{l}\text { Kanpona, } \\
\text { Choukkani }\end{array}$ & $\begin{array}{l}\text { D. } 7 ; \mathrm{P}_{1} . \\
\text { 13; } \mathrm{P}_{2} \\
\text { 6; A. } 16\end{array}$ \\
\hline Beloniformes & Hemiramphidae & Dermogenyspusilla & $\begin{array}{l}\text { Wrestling } \\
\text { Halfbeak }\end{array}$ & EkThota & $\begin{array}{l}\text { D. 9; P1. } \\
\text { 10; P2. } 6 \text {; } \\
\text { A. } 14\end{array}$ \\
\hline Beloniformes & Belonidae & Xenentodoncancila & $\begin{array}{l}\text { Freshwater } \\
\text { Garfish, } \\
\text { Needle Fish }\end{array}$ & $\begin{array}{l}\text { Kankila, } \\
\text { Kaikya, } \\
\text { Kakila }\end{array}$ & $\begin{array}{l}\text { D 15; } \mathrm{P}_{1} \\
10 ; \mathrm{P}_{2} 6 ; \mathrm{A} \\
18 .\end{array}$ \\
\hline Cypriniformes & Cyprinidae & Bariliusvagra & VagraBaril & $\begin{array}{l}\text { Vagra, } \\
\text { Koksa }\end{array}$ & $\begin{array}{l}\text { D. 9; P1. } \\
13 ; \text { P2. 9; } \\
\text { A. } 12\end{array}$ \\
\hline Cypriniformes & Cyprinidae & Puntiusterio & One spot barb & $\begin{array}{l}\text { Teri puti } \\
\text { and Puti }\end{array}$ & $\begin{array}{l}\text { D. } 11 ; \mathrm{P} 1 \text {. } \\
\text { 14; P2. 9; } \\
\text { A. } 8\end{array}$ \\
\hline Cypriniformes & Cobitidae & Lepidocephalusberdmorei & $\begin{array}{l}\text { Burmese } \\
\text { Loach }\end{array}$ & Puiya & $\begin{array}{l}\text { D 2/6; } \mathrm{P}_{1} 8 \\
\mathrm{P}_{2} 6 ; \mathrm{A} 2 / 5\end{array}$ \\
\hline Perciformes & Pristolepidae & Badisbadis & $\begin{array}{l}\text { Badis, Dwarf } \\
\text { Chameleonfish }\end{array}$ & $\begin{array}{l}\text { Koi Bandi, } \\
\text { Napit }\end{array}$ & $\begin{array}{l}\text { D. XVI/9; } \\
\text { P1. 13; P2. } \\
\text { I/5; A. III/7 }\end{array}$ \\
\hline Perciformes & Mastacembelidae & Mastacembelusarmatus & $\begin{array}{l}\text { Tire-track } \\
\text { Spiny Eel }\end{array}$ & $\begin{array}{l}\text { Baim, Sal } \\
\text { Baim, } \\
\text { Bain, } \\
\text { Bamosh, }\end{array}$ & $\begin{array}{l}\mathrm{D} \\
\text { XXXVII/82; } \\
\mathrm{P}_{1} 24\end{array}$ \\
\hline Perciformes & Gobiidae & Glossogobiusgiuris & Tank goby & $\begin{array}{l}\text { Bele, } \\
\text { Bailla }\end{array}$ & $\begin{array}{l}D_{1} .6, D_{2} . \\
9-10, P_{2} .6, \\
\text { A. } 9-10\end{array}$ \\
\hline
\end{tabular}

During the study period a total of 120 fishes were collected. The fishes belong to 6 orders and 10 families (Table 3). Among the collected species, Oder Cypriniformes was recorded as most diversified fish group in terms of both number of sepeies and individual. The relative abundance of fishes belongs to different families (Table 3). The order Cypriniformes comprised by $40 \%$ and next abundance in order Perciformes which was comprised of $25 \%$ and the rest of the order such as the order Beloniformes, Siluriformes, and Cyprinodontiformes 
comprised of $10 \%$, respectively. The order Elopiformes occupied only 5\% (Fig. 10).

The order Cypiniformes comprised of four families, namely Psilorhynchidae, Cyprinidae, Cobitidae, and Balitoridae had 10\%, respectively (Fig. 11). The order Beloniformes having two families Belonidae and Hemiramphidae had 5\%, respectively. The order Elopiformes having only one family, namely Ophichthidae and the percentage was 5\%. The order Perciformes having three families namely Mastacembelidae, Pristolepidae, and Gobiidae and the percentageswas 10, 10 and 5, respectively. The order Siluriformes having one family, namely Olyridae, the percentage was 10. The remaining order, namely Cyprinodontiformes having only one family namely Cyprinodontidae the percentage was 10 (Fig. 10).

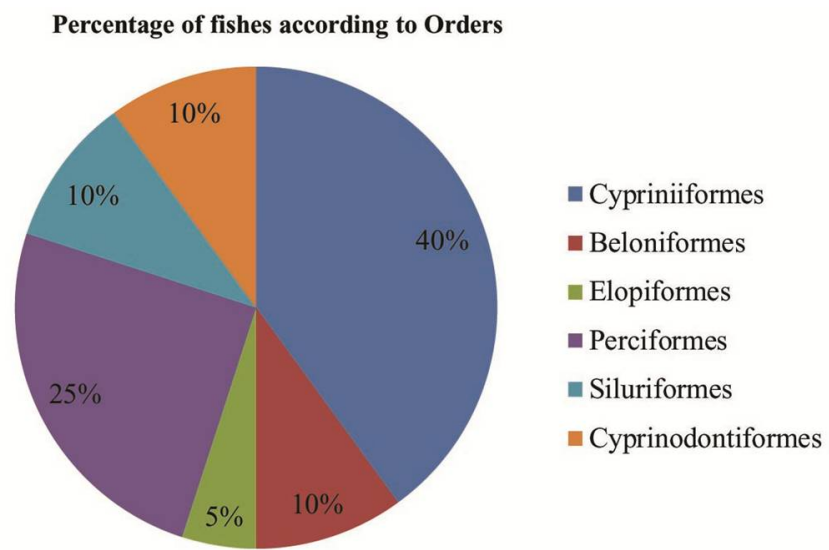

Fig. 10. Relative abundance of fishes belonging to different orders of Chengi river.

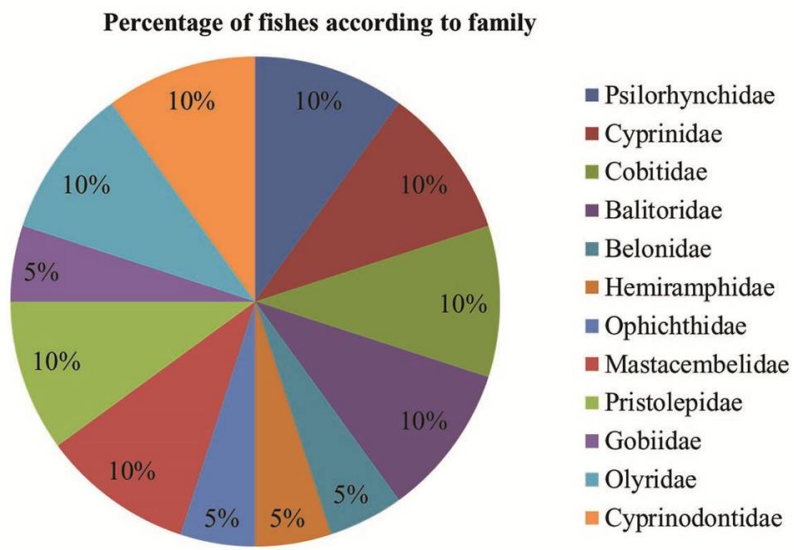

Fig. 11. Distribution of different families of fishes of the Chengi river. 


\section{CONCLUSION}

Chengi river is precious assets of Khagrachari district with unique regional characteristics. The results revealed that the DO, TDS, EC, temperature, transparency, turbidity, remained within the Bangladesh standard range during summer season, which was a good sign. The $\mathrm{pH}$ increased to a large extent during the summer period of the year which is very alarming both for the aquatic and human life. The number and variety of fishes are disappearing over the time. Continuous waste dumping, sewage disposal, overhanging latrines, waste from slaughterhouses, continuous land grabbing etc. are making the situation more critical day by day. So, it is high time for the authority to focus on these problem sources and come forward with mitigating measures.

Acknowledgement: Authors would like to express the deep gratitude to Abdullah Al Nayeem, and Md. Nasir Ahmed Patoary, Department of Environmental Science, Stamford University Bangladesh for their kind cooperation.

\section{LITERATURE CITED}

ABEGAZ, S. 2007. Pollution status of Tinishu Akaki River and its tributaries (Ethiopia) evaluated using physicochemical parameters, major ions, and nutrients. Bull. Chem. Soc. Ethiop. 21(1): 13-22.

ARIS, A.Z., LIM, W.Y., PRAVEENA, S.M., YUSOFF, M.K., RAMLI, M.F. and JUAHIR, H. 2014. Water Quality Status of Selected Rivers in Kota Marudu, Sabah, Malaysia and its Suitability for Usage.Sains Malaysiana 43(3): 377-388

BALA, B.K., HAQUE, M.A., HOSSAIN, M.A., HOSSAIN, S.M.A. and MAJUMDAR, S. 2010. Management of Agricultural Systems of the Upland of Chittagong Hill Tracts for Sustainable Food Security.

BBS. 2011. Bangladesh Population Census, Ministry of Planning, Government of the People's Republic of Bangladesh. 4: 341.

COOPER, J., REDISKE, R., NORTHUP, M., THOGERSON, M. and DENEND, J. V. 1998. Agriculture Water Guality index. Scientific Reports, Annis Water Resources Institute, pp.1-49.

HANNAN, M. 2013. Khagrachari District Information.

KUMAR, A. and DUA, A. 2009.Water Quality Index for assessment of Water Quality of River Ravi at Madhopur- India, Global Journal of Environmental Sci. 8: 49-57.

PARVIN, M.M. 2007. Quality of the life in Dhaka City: A GIS and Environmental Approach; Unpublished Thesis, Department of Geography and Environment, University of Dhaka. pp. 89

RAHAMAN, Z.A., RUS, S.C., OMAR, M.A. and ISMAIL, W. 2016. Rivers and Lakes as Natural Heritage: Water Quality Status in the Northern States of Peninsular Malaysia. The Asian Journal of Humanities 23(1): 109-128

TALWAR, P.K. and JHINGRAN, A.G. 1991.Inland fishes of India and Adjacent Countries, Vol. I, Oxford \& IBH Publishing Co. Pvt. Ltd., New Delhi-Calcutta, pp. 537-538. 
TIWARI, A., DWIVEDI, A. and MAYANK, P. 2016. Time Scale Changes in the Water Guality of the Ganga River, and Estimation of Suitability for Exotic and Hardy Fishes. Hydrology Current Res. 7(3): $1-8$

UDDIN M., ALAM, M., MOBIN, M. and MIAH, M. 2014. An Assessment of the River Water Quality Parameters: A case of Jamuna River. Journal of Environmental Science 7(1): 249-256.

(Manuscript received on 13 March, 2019; revised on 17 November, 2019) 